\title{
Comparison of the Allometry Coefficient of the Length-Weight and Length-Length Relationship between Selene brownii, S. vomer and $S$. setapinnis Caught in the Gulf of Mexico
}

\author{
Comparación del Coeficiente de Alometría de la Relación Talla-Peso y Longitud-Longitud \\ entre Selene brownii, $S$. vomer y $S$. setapinnis Capturados en el Golfo de México
}

\section{B. Farías-Tafolla*; J. De la Cruz-Torres"***; A. Ponce-Rodríguez; J. R. Gersenowies-Rodríguez ;} J. A. Martínez-Pérez* \& M. M. Chávez-Arteaga*

FARÍAS-TAFOLLA, B.; DE LA CRUZ-TORRES, J.; PONCE-RODRÍGUEZ, A.; GERSENOWIES-RODRÍGUEZ, J. R.; MARTÍNEZ-PÉREZ, J.A. \& CHÁVEZ-ARTEAGA, M. M. Comparison of the allometry coefficient of the length-weight and lengthlength relationship between Selene brownii, S. vomer and S. setapinnis caught in the Gulf of Mexico. Int. J. Morphol., 33(4):1237-1241, 2015.

SUMMARY: This work presents a comparison of the length-weight and length-length allometric relationships between six measurements: length pattern (LP), cephalic length (CL), maximum depth (MA), caudal peduncle depth (CPD) ocular diameter (OD) and weight (W) of three species of the genus Selene (S. brownii, S. vomer and S. setapinnis) caught in the port of Veracruz, Mexico, using a beach seine of $800 \mathrm{~m}$. The results show certain relationships between all measurements of $S$. brownii (an isometric relationship and four negative allometric relationships); S. vomer showed only four relationships (two isometric and two negative allometric); and S. setapinnis showed three relationships (all negative allometric); the results of $S$. vomer and S. setapinnis are consistent with those reported by Muto et al. (2010). The comparison of the coefficients of allometry between the three species allowed us to determine that $S$. brownii and $S$. vomer differed significantly in two of the four allometric coefficients of length-weight relationships common to them, and in three of the four allometric coefficients of length-length relationships common to them. S. brownii and S. setapinnis differed significantly in two of the three allometric coefficients of length-weight relationships common to them and in the only allometric coefficient of length-length relationships common to them. Finally, S. vomer and S. setapinnis differed significantly in the three common allometric coefficients of length-weight relationships, and in the only common allometric coefficient of length-length relationship.

KEY WORDS: Selene; Allometric analysis; Length-weight and length-length relationships; Coefficient of allometry.

\section{INTRODUCTION}

The length-weight (L-W) and length-length (L-L) relationships are important parameters to know the biology of osteichthyes because they provide information about their growth patterns and about the conditions of the region they inhabit (Agboola \& Anetekhai, 2008). The length-weight relationships also help us understand the diseases, the reproductive history, life history and general health of the species of commercial importance (Kara \& Bayhan, 2008); they are also useful for morphological and life form comparisons of local and interregional species and populations. Length-weight studies typically involve estimating the mass of fish of a certain body length, determining body condition factors (an interpretation of relative prosperity and maturity) and the conversion of length-growth models into weightgrowth models (King, 1996).

In order to obtain more reliable results when comparing populations, it is necessary to use standard measures for each of them. Thus, it is very useful to determine the length-length relationships of species in different environmental conditions; they are also important for comparative studies of relative growth (Moutopoulos \& Stergiou, 2002). In studies of fisheries, it is often more easy and quick to measure the length of the fish than their body mass. Knowing the length-weight relationship of a particular species makes it easier to determine its mass when only the length is known; however, in some

\footnotetext{
Laboratorio de Zoología, Facultad de Estudios Superiores Iztacala, Universidad Nacional Autónoma de México, Tlalnepantla, México.

* Laboratorio de Anatomía Animal Comparada Unidad de Morfología y Función, Facultad de Estudios Superiores Iztacala, Universidad Nacional Autónoma de México, Tlalnepantla, México.

**** Posgrado en Ciencias del Mar y Limnología, ICMyL, Universidad Nacional Autónoma de México, México DF, México.
} 
FARÍAS-TAFOLLA, B.; DE LA CRUZ-TORRES, J.; PONCE-RODRÍGUEZ, A.; GERSENOWIES-RODRÍGUEZ, J. R.; MARTÍNEZ-PÉREZ, J. A. \& CHÁVEZ-ARTEAGA, M. M.

Comparison of the allometry coefficient of the length-weight and length-length relationship between Selene brownii, S. vomer and S. setapinnis caught in the Gulf of Mexico. Int. J. Morphol., $33(4): 1237-1241,2015$

cases it is not possible to take morphometric measurements properly because the fins are easily damaged at the time of sampling, particularly the caudal fin, making it difficult to measure total length accurately; thus, the standard length can be used to estimate total length within an acceptable error margin (Moutopoulos \& Stergiou, 2002).

No studies have focused on this type of body relationships in the group of fish belonging to the genus Selene because they have no commercial significance; however, they belong to a family with great morphological variability. The studies that have focused on this group have researched aspects related to the phylogenetic relationships (Reed et al., 2001; Uedson et al., 2013), morphological differences between juveniles (Lima-Filho et al., 2006) and larval development of some species (Katsuragawa, 1997); only Muto et al. (2000) present data on the length-weight relationship of $S$. vomer and $S$. setapinnis species caught in southeastern Brazil, using only total length and weight and without considering other measures of length.

Since there is no allometric study of the length-weight and length-length relationships of Selene brownii, S. vomer and $S$. setapinnis, the objective of this study was to determine the length-weight and length-length relationships of these species, which are present in the coast of Veracruz, and to compare their allometric coefficients.

\section{MATERIAL AND METHOD}

A total of 102 organisms were caught in the port of Veracruz, Mexico (10 $\left.11^{\prime} 43^{\prime \prime} \mathrm{N}, 96^{\circ} 07^{\prime} 37^{\prime \prime} \mathrm{W}\right)$, using a beach seine of $800 \mathrm{~m}$ in length and 4 inches mesh size. The specimens were transported to the Zoology laboratory of FES-Iztacala and then identified using the keys of Carpenter (2002). A caliper with an accuracy of $0.001 \mathrm{~cm}$ was used to obtain the following morphometric measurements: length pattern (LP), cephalic length (CL), maximum depth (MA), caudal peduncle depth (CPD) and ocular diameter (OD) (Fig. 1). Weight (W) was measured using a semi-analytical balance with a resolution of $0.001 \mathrm{~g}$.

Allometric analysis: All analysis was based on the allometric function (Huxley, 1950): $y=a^{b}$

Where:

$\mathrm{x}=\mathrm{a}$ variable that represents in overall terms the largest organic portion.

$\mathrm{y}=\mathrm{a}$ variable that represents in overall terms the smallest organic portion.

$\mathrm{a}=$ constant

$\mathrm{b}=$ allometric growth constant.
In order to use this equation, it must be logarithmically transformed (Kamaruddin et al., 2011): $\log _{10} y=\log _{10} a+b \log _{10} x$

Since "b" is the slope of the equation and is equal to the allometric growth constant expressing the relationship between two variables ( $\mathrm{x}$ and $\mathrm{y}$ ), it was used for a statistical test for the morphometric measurements; $b>1$ indicates positive allometric growth, $b=1$ isometric growth and $b<1$ negative allometric growth (da Silva-Castiglioni \& Negreiros-Fransozo, 2004). The value "b" was tested using a Student's t-test (Ho: $b=1, \partial=5 \%)$ (Sokal \& Rohlf, 1987).

When comparing the measurements with weight, the length measurements were always taken as "x", while weight was taken as "y"; in these conditions, isometric growth occurs when $b=3$, i.e., the relative growth of both variables is identical (Mayrat, 1970; Quinn II \& Deriso, 1999). When the value of $b$ is $<3$, there can be said to be a negative allometric growth; when the value of $b$ is $>3$, there is positive allometric growth (Shingleton et al., 2009). The value "b" was tested using a Student's t-test (Ho: $b=3 \partial=5 \%$ ) (Sokal \& Rohlf).

We also used a Student's t-test to compare the allometric coefficients between the different species (Ho: $b_{\text {Selene }} 1=b_{\text {Selene }} 2 \partial=5 \%$ ) (Steel \& Torrie, 1980).

All calculations were performed using the STATISTICA software package ver. 8 (StatSoft, Inc. 2007).

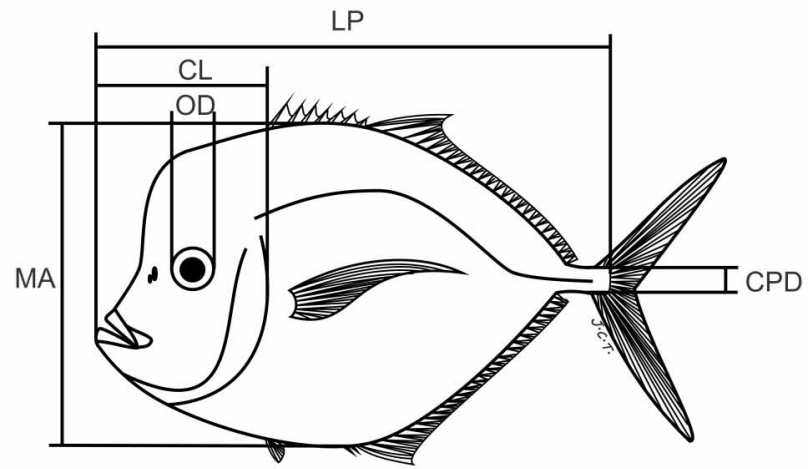

Fig. 1. Biometric measurements of the studied specimens.

\section{RESULTS AND DISCUSSION}

Table I shows the length-weight relationships that had a significant correlation for the three species. It is noteworthy that of five possible combinations, $S$. brownii had all of them, $S$. vomer only four and $S$. setapinnis three. These data are statistically the same for the allometric constant of $S$. vomer and S. setapinnis to those obtained by Muto et al. for the 
FARÍAS-TAFOLLA, B.; DE LA CRUZ-TORRES, J.; PONCE-RODRÍGUEZ, A.; GERSENOWIES-RODRÍGUEZ, J. R.; MARTÍNEZ-PÉREZ, J. A. \& CHÁVEZ-ARTEAGA, M. M.

Comparison of the allometry coefficient of the length-weight and length-length relationship between Selene brownii, S. vomer and S. setapinnis caught in the Gulf of Mexico. Int. J. Morphol., 33(4): 1237-1241,2015.

same species ( $S$. setapinnis $\mathrm{a}=3.236 \mathrm{E}-05, \mathrm{~b}=2796 ;$ S. vomer $\mathrm{a}=4.236 \mathrm{E}-05, \mathrm{~b}=2.746)$. Significant differences are observed in the case of constant "a", since it depends on the conditions of the ecosystem (Cifuentes et al., 2012). It is noteworthy that there were many negative allometric relationships; this implies that the weight of the portions considered had a slower relative growth rate, that is, the organisms tend to be thinner. This phenomenon is a process described for several species of vertebrates (McMahon, 1973).

Table II shows the length-length relationships that had a significant correlation for the three species. Of four possible combinations, S. brownii had all of them, S. vomer only had three and $S$. setapinnis had one. These data had no point of comparison in the literature consulted; thus, we believe these are the first published values and will serve as reference for future studies. It is worth noting the great number of isometric relationships. In the case of those related to length pattern (LP), this implies a constant rate of relative growth, i.e., the proportions between cephalic length (CL), maximum depth (MA), caudal peduncle depth (CPD) and ocular diameter (OD) tend not to change significantly as the organism grows. This phenomenon is observed in static allometry, with organisms of the same age group.

Table III shows the results of the comparison between the length-weight allometric constants common to the different species. Thus, we can see that:
1) When comparing $S$. brownii and $S$. vomer with respect to $\mathrm{LP}$ vs $\mathrm{W}$ and $\mathrm{CL}$ vs $\mathrm{W}$, the value of the allometric constant is greater than for $S$. brownii, implying that $S$. vomer tends to be more graceful with respect to these relationships. With respect to MA vs W, the allometric coefficient of $S$. vomer is greater than that of $S$. brownii, implying that $S$. brownii is more graceful with respect to that relationship. With respect to CPD vs W, the allometric constants for S. brownii and S. vomer did not show statistical differences.

2) When comparing S. brownii and S. setapinnis with respect to MA vs $\mathrm{W}$ and $\mathrm{CPD}$ vs $\mathrm{W}$, the value of the allometric constant was greater for S. brownii, implying that S. setapinnis is more graceful than $S$. brownii with respect to these relationships. With respect to CL vs W, the allometric constant for S. brownii and $S$. setapinnis did not show statistical differences.

3) When comparing $S$. vomer and S. setapinnis with respect to $\mathrm{MA}$ vs $\mathrm{W}$ and CPD vs $\mathrm{W}$, the value of the allometric constant is greater for $S$. vomer, implying that $S$. setapinnis tends to be more graceful with respect to these relationships. However, with respect to CL vs W, the allometric coefficient of $S$. setapinnis was greater than that of $S$. vomer, implying that $S$. vomer is more graceful with respect to this relationship.

Table IV shows the results of the comparison between the length-length allometric constants common to the different species. Thus, we can see that:

Table I. Weight-Length relationship.

\begin{tabular}{llcccccc}
\hline Measure & Species & $\mathbf{n}$ & $\mathbf{b}$ & $\mathbf{a}$ & $\mathbf{r}$ & $\mathbf{p}$ & Behavior \\
\hline LP vs W & S. brownii & 73 & 2.84060827 & 0.01521733 & 0.89505558 & 0.001 & Isometric \\
CL vs W & S. brownii & 73 & 2.2315366 & 0.17416513 & 0.76241429 & 0.0001 & Negative Allometric \\
MA vs W & S. brownii & 73 & 2.22080213 & 0.09570338 & 0.83729059 & 0.001 & Negative Allometric \\
CPD vs W & S. brownii & 73 & 2.3283282 & 1.11206682 & 0.88516014 & 0.001 & Negative Allometric \\
OD vs W & S. brownii & 73 & 2.16421804 & 0.68665266 & 0.85364171 & 0.001 & Negative Allometric \\
LP vs W & S. vomer & 9 & 2.4493607 & 0.03694868 & 0.96782234 & 0.001 & Negative Allometric \\
CL vs W & S. vomer & 9 & 1.27933035 & 0.86628418 & 0.84183518 & 0.001 & Negative Allometric \\
MA vs W & S. vomer & 9 & 2.46882803 & 0.05500725 & 0.84483186 & 0.001 & Isometric \\
CPD vs W & S. vomer & 9 & 2.36038048 & 0.9884998 & 0.90480668 & 0.001 & Isometric \\
CL vs W & S. setapinnis & 20 & 2.01029607 & 0.2367374 & 0.6710077 & 0.001 & Negative Allometric \\
MA vs W & S. setapinnis & 20 & 1.44570809 & 0.46020957 & 0.70096038 & 0.001 & Negative Allometric \\
CPD vs W & S. setapinnis & 20 & 1.6565824 & 1.99006134 & 0.61231192 & 0.001 & Negative Allometric \\
\hline
\end{tabular}

Table II. Length-Length relationship.

\begin{tabular}{llcccccc}
\hline Measure & Species & $\mathbf{n}$ & $\mathbf{b}$ & $\mathbf{a}$ & $\mathbf{r}$ & p & Behavior \\
\hline LP vs CL & S. brownii & 73 & 0.91671158 & 0.74729906 & 0.84544305 & 0.001 & Isometric \\
LP vs MA & S. brownii & 73 & 0.95952441 & 0.89637533 & 0.801915 & 0.0001 & Isometric \\
LP vs CPD & S. brownii & 73 & 0.89577917 & 0.32821968 & 0.74244103 & 0.0001 & Isometric \\
LP vs OD & S. brownii & 73 & 0.98331328 & 0.36064461 & 0.78551764 & 0.0001 & Isometric \\
LP vs CL & S. vomer & 9 & 1.48120176 & 0.22697554 & 0.889432 & 0.001 & Isometric \\
LP vs MA & S. vomer & 9 & 0.78629508 & 1.35752835 & 0.90792299 & 0.001 & Isometric \\
LP vs CPD & S. vomer & 9 & 0.84206235 & 0.38725217 & 0.86798728 & 0.002 & Isometric \\
LP vs CPD & S. setapinnis & 20 & 0.18941832 & 1.51997444 & 0.58043901 & 0.007 & Negative Alometric
\end{tabular}


FARÍAS-TAFOLLA, B.; DE LA CRUZ-TORRES, J.; PONCE-RODRÍGUEZ, A.; GERSENOWIES-RODRÍGUEZ, J. R.; MARTÍNEZ-PÉREZ, J. A. \& CHÁVEZ-ARTEAGA, M. M.

Comparison of the allometry coefficient of the length-weight and length-length relationship between Selene brownii, S. vomer and S. setapinnis caught in the Gulf of Mexico. Int. J. Morphol., 33(4):1237-1241,2015.

Table III. Comparison of the length-weight allometric constants between the different species.

\begin{tabular}{|c|c|c|c|c|c|c|}
\hline Measure & Species & n & b & $S^{2} y x$ & $\mathbf{t}_{\text {observed }}$ & $\mathbf{p}$ \\
\hline \multirow[t]{2}{*}{ LP vs W } & S. brownii & 73 & 2.84060827 & 0.00332562 & \multirow{2}{*}{5.99437683} & \multirow{2}{*}{$<0.005$} \\
\hline & S. vomer & 9 & 2.4493607 & 0.00093443 & & \\
\hline \multirow[t]{2}{*}{ CL vs W } & S. brownii & 73 & 2.2315366 & 0.00700196 & \multirow{2}{*}{8.95721545} & \multirow{2}{*}{$<0.005$} \\
\hline & S. vomer & 9 & 1.27933035 & 0.00429902 & & \\
\hline \multirow[t]{2}{*}{ MA vs W } & S. brownii & 73 & 2.22080213 & 0.00499899 & \multirow{2}{*}{-2.5825648} & \multirow{2}{*}{$<0.01$} \\
\hline & S. vomer & 9 & 2.46882803 & 0.00422443 & & \\
\hline \multirow[t]{2}{*}{ CPD vs W } & S. brownii & 73 & 2.3283282 & 0.0036202 & \multirow{2}{*}{-0.4039467} & \multirow{2}{*}{$>0.05$} \\
\hline & S. vomer & 9 & 2.36038048 & 0.00267587 & & \\
\hline \multirow[t]{2}{*}{ CL vs W } & S. brownii & 73 & 2.2315366 & 0.00700196 & \multirow{2}{*}{1.98359132} & \multirow{2}{*}{$>0.05$} \\
\hline & S. setapinnis & 20 & 2.01029607 & 0.00543817 & & \\
\hline \multirow[t]{2}{*}{ MA vs W } & S. brownii & 73 & 2.22080213 & 0.00499899 & \multirow{2}{*}{7.73908954} & \multirow{2}{*}{$<0.005$} \\
\hline & S. setapinnis & 20 & 1.44570809 & 0.00503166 & & \\
\hline \multirow[t]{2}{*}{ CPD vs W } & S. brownii & 73 & 2.3283282 & 0.0036202 & \multirow{2}{*}{6.7844475} & \multirow{2}{*}{$<0.005$} \\
\hline & S. setapinnis & 20 & 1.6565824 & 0.0061833 & & \\
\hline \multirow[t]{2}{*}{ CL vs W } & S. vomer & 9 & 1.27933035 & 0.00429902 & \multirow{2}{*}{-7.4076472} & \multirow{2}{*}{$<0.005$} \\
\hline & S. setapinnis & 20 & 2.01029607 & 0.00543817 & & \\
\hline \multirow[t]{2}{*}{ MA vs W } & S. vomer & 9 & 2.46882803 & 0.00422443 & \multirow{2}{*}{10.6343954} & \multirow{2}{*}{$<0.005$} \\
\hline & S. setapinnis & 20 & 1.44570809 & 0.00503166 & & \\
\hline \multirow[t]{2}{*}{$\mathrm{CPD}$ vs $\mathrm{W}$} & S. vomer & 9 & 2.36038048 & 0.00267587 & \multirow{2}{*}{7.47741574} & \multirow{2}{*}{$<0.005$} \\
\hline & S. setapinnis & 20 & 1.6565824 & 0.0061833 & & \\
\hline
\end{tabular}

Table IV. Comparison of the length-length allometric coefficients between different species.

\begin{tabular}{llccccc}
\hline Measure & Species & $\mathbf{n}$ & $\mathbf{b}$ & $\mathbf{S}^{\mathbf{2} \mathbf{x}}$ & $\mathbf{t}_{\text {observed }}$ & $\mathbf{p}$ \\
\hline LP vs CL & S. brownii & 73 & 0.91671158 & 0.00055674 & -12.978773 & $<0.005$ \\
& S. vomer & 9 & 1.48120176 & 0.00133493 & & \\
LP vs MA & S. brownii & 73 & 0.95952441 & 0.00084842 & 5.10381244 & $<0.005$ \\
& S. vomer & 9 & 0.78629508 & 0.00030358 & & \\
LP vs CPD & S. brownii & 73 & 0.89577917 & 0.00108463 & 1.33486342 & $>0.05$ \\
& S. vomer & 9 & 0.84206235 & 0.00053474 & & \\
LP vs CPD & S. brownii & 73 & 0.89577917 & 0.00108463 & 15.8711543 & $<0.005$ \\
& S. setapinnis & 20 & 0.18941832 & 0.00089615 & & \\
LP vs CPD & S. vomer & 9 & 0.84206235 & 0.00053474 & 17.2533202 & $<0.005$ \\
& S. setapinnis & 20 & 0.18941832 & 0.00089615 & & \\
\hline
\end{tabular}

1) When comparing $S$. brownii and $S$. vomer with respect to LP vs CL, the value of the allometric constant is greater for $S$. vomer, implying that the cephalic length of $S$. vomer tends to grow at a higher rate than that of $S$. brownii. However, with respect to LP vs MA, the allometric coefficient of $S$. brownii is greater than that of $S$. vomer, which implies that the maximum height of $S$. brownii has a higher growth than that of $S$. vomer. With respect to LP vs CPD, the allometric constants of $S$. brownii and $S$. vomer did not show statistical differences.

2) When comparing $S$. brownii and $S$. setapinnis with respect to LP vs CPD, the value of the allometric constant is greater for $S$. brownii, indicating that the relative growth of the amplitude of the tail peduncle of $S$. brownii is higher than that of $S$. setapinnis.

3) When comparing $S$. vomer and S. setapinnis with respect to LP vs CPD, the value of the allometric constant is greater for
$S$. vomer, indicating that the relative growth of the amplitude of the tail peduncle is higher in $S$. vomer than in S. setapinnis.

One of the most prominent morphological characteristics of this genus of fish in the Mexican Atlantic is that they have a large number of negative length-weight allometric relationships, indicating that these species tend to be extremely thin; thus their common name of "Papelillos". Another noteworthy feature of the weight-length relationship is an isometric condition, which indicates constant ontogenetic growth, i.e., that the body proportions do not change, which is very important for the identification of juveniles, since taxonomic keys are based on the characteristics of adults. The comparison of the species showed us that S. setapinnis is the thinnest of the three species studied; nevertheless, $S$. vomer has the smallest head of all. In terms of growth rate, we can say that $S$. brownii grows faster than the other two, which we can be very useful if these species ever become economically important. 
FARÍAS-TAFOLLA, B.; DE LA CRUZ-TORRES, J.; PONCE-RODRÍGUEZ, A.; GERSENOWIES-RODRÍGUEZ, J. R.; MARTÍNEZ-PÉREZ, J. A. \& CHÁVEZ-ARTEAGA, M. M.

Comparison of the allometry coefficient of the length-weight and length-length relationship between Selene brownii, S. vomer and S. setapinnis caught in the Gulf of Mexico. Int. J. Morphol., 33(4):1237-1241, 2015.

FARÍAS-TAFOLLA, B.; DE LA CRUZ-TORRES, J.; PONCE-RODRÍGUEZ, A.; GERSENOWIES-RODRÍGUEZ, J. R.; MARTÍNEZ-PÉREZ, J. A. \& CHÁVEZ-ARTEAGA, M. M. Comparación del coeficiente de alometría de la relación talla-peso y longitud-longitud entre Selene brownii, S. vomer y S. setapinnis capturados en el Golfo de México. Int. J. Morphol., 33(4):1237-1241, 2015.

RESUMEN: En este trabajo se presentan las comparaciones de las relaciones alométricas de longitud- peso y longitud-longitud de seis medidas (longitud patrón (LP), longitud cefálica (LC), amplitud máxima (AM), amplitud del pedúnculo (AP), diámetro ocular (DO) y Peso (W) de tres especies del género Selene (S. brownii, S. vomer y S. setapinnis) capturados en el puerto de Veracruz México, mediante el uso de un chinchorro playero de $800 \mathrm{~m}$. Los resultados obtenidos muestran que $S$. brownii posee relaciones entre todas sus medidas (una isométrica y cuatro alométricas negativas), $S$. vomer posee solo cuatro relaciones (dos isométricas y dos alométricas negativas) y S. setapinnis posee tres relaciones (todas alométricas negativas), los resultados de $S$. vomer y $S$. setapinnis concuerdan con los reportados por Muto et al. (2010). Al comparar los coeficientes de alometría entre las tres especies se pudo determinar que S. brownii y S. vomer difieren significativamente en dos de los cuatro coeficientes alométricos comunes en las relaciones longitud-peso, y tres de los cuatro coeficientes alométricos comunes en las relaciones longitud-longitud; S. brownii y S. setapinnis difieren significativamente en dos de los tres coeficientes alométricos comunes en las relaciones longitud-peso y en el único coeficiente alométricos común en las relaciones longitud-longitud; por último $S$. vomer y $S$. setapinnis difieren significativamente en los tres coeficientes alométricos comunes en la relaciones longitud-peso, y en el único coeficiente alométrico común en las relaciones longitud-longitud.

PALABRAS CLAVE: Selene; Análisis alométrico; Relaciones longitud-peso y longitud-longitud; Coeficiente de alometría.

\section{REFERENCES}

Agboola, J. I. \& Anetekhai, M. A. Length-weight relationships of some fresh and brackish water fishes in Badagry creek, Nigeria. J. Appl. Ichthyol., 24(5):623-5, 2008.

Carpenter, K. E. (Ed.). The living marine resource of the Western Central Atlantic. Vol. 3: Bony fishes part 2 (Opistognathidae to Molidae), sea turtles and marine mammals. Roma, FAO Species Identification Guide for Fishery Purposes and American Society of Ichthyologists and Herpetologists Special Publication No. 5, 2002.

Cifuentes, R.; González, J.; Montoya, G.; Jara, A.; Ortíz, N.; Piedra, P. \& Habit, E. Relación longitud-peso y factor de condición de los peces nativos del río San Pedro (cuenca del río Valdivia, Chile). Gayana (Concepc.), 75(1):101-10, 2012.

da Silva Castiglioni, D. \& Negreiros-Fransozo, M. L. Comparative analysis of the relative growth of Uca rapax (Smith) (Crustacea, Ocypodidae) from two mangroves in São Paulo, Brazil. Rev. Bras. Zool., 21(1):13744, 2004.

Huxley, J. S. A discussion on the measurement of growth and form; relative growth and form transformation. Proc. R. Soc. Lond. B Biol. Sci., 137(889):465-9, 1950

Kamaruddin, I. S.; Mustafa-Kamal, A. S.; Christianus, A.; Daud, S. K.; Amin, S. M. N. \& Yu-Abit, L. Length-weight Relationship and condition factor of three dominant species from the lake Tasik Kenyir, Terengganu, Malaysia. J. Fish. Aquat. Sci., 6(7):852-6, 2011.

Kara, A. \& Bayhan, B. Length-weight and length-length relationships of the bogue Boops boops (Linneaus, 1758) in Izmir Bay (Aegean Sea of Turkey). Belg. J. Zool., 138(2):154-7, 2008.

Katsuragawa, M. Larval Development of the atlantic moonfish Selene setapinnis (Osteichthyes, Carangidae) from southeastern Brazil. Bull. Mar. Sci., 61(3):779-89, 1997.

King, R. P. Length-weight relationships of Nigerian freshwater fishes. Naga WorldFish Cent. Newsl., 19(3):49-52, 1996.

Lima-Filho, J. M.; Lessa, R.; Stosic, B.; Duarte Neto, P. J. \& Vieira, J. W. Morphological discrimination in juveniles of two Selene Species (Teleostei: Carangidae) using truss net distances. Braz. Arch. Biol. Technol., 49(2):231-8, 2006.
Mayrat, A. Allometrie et taxinomie. Rév. Stat. Appl., 18:47-58, 1970.

McMahon, T. Size and shape in biology. Science, 179(4079):1201-4, 1973.

Moutopoulos, D. K. \& Stergiou, K. I. Length-weight and length-length relationships of fish species from the Aegean Sea (Greece). J. Appl. Ichthyol., 18(3):200-3, 2002.

Muto, E. Y.; Soares, L. S. H. \& Rossi-Wongtschowski, C. L. D. B. LengthWeight Relationship of Marine Fish Species off São Sebastião System, São Paulo, Southeastern Brazil. Naga ICLARM Q., 23(4):27-9, 2000.

Quinn II, T. J. \& Deriso, R. B. Quantitative Fish Dynamics. New York, Oxford University Press, 1999.

Reed, D. L.; deGravelle, M. J. \& Carpenter, K. E. Molecular systematics of Selene (Perciformes: Carangidae) based on cytochrome B sequences. Mol. Phylogenet. Evol., 21(3):468-75, 2001.

Shingleton, A. W.; Estep, C. M.; Driscoll, M. V. \& Dworkin, I. Many ways to be small: different environmental regulators of size generate distinct scaling relationships in Drosophila melanogaster. Proc. Biol. Sci., 276(1667):2625-33, 2009.

Sokal, R. R. \& Rohlf, F. J. Introduction to Biostatistics. 2nd ed. New York, Freeman, 1987.

Steel, R. G. D. \& Torrie, J. H. Principles and procedures of statistics: a biometrical approach. New York, McGraw-Hill, 1980.

Uedson, P. J.; Vicari, M. R.; Martínez, P. A.; de Bello Cioffi, M.; Bertollo, L. A. C. \& Molina, W. F. Atlantic moonfishes: independent pathways of karyotypic and morphological differentiation. Helgoland Mar. Res., 67(3):499-506, 2013

Correspondence to:

Biol. Jonathan De la Cruz Torres

Polonia 43 Col. México 86

Naucalpan de Juárez

Estado de México, C.P. 53428

MÉXICO

Email: jct990@outlook.com

Received: 09-04-2015

Accepted: 02-09-2015 